SAKAI SAMBAYAN — Jurnal Pengabdian kepada Masyarakat

\title{
PENERAPAN MESIN PEMBUAT TEPUNG IKAN RUCAH DI KECAMATAN PASIR SAKTI LAMPUNG TIMUR
}

\author{
Warji $^{1^{*}}$, Budianto Lanya ${ }^{1}$, dan Rakhmawati ${ }^{2}$ \\ ${ }^{1}$ Jurusan Ilmu Keteknikan Pertanian, Fakultas Pertanian, Universitas Lampung, Bandar Lampung \\ Jl. Prof. Sumantri Brojonegoro No.1 Bandar Lampung 35145 \\ ${ }^{2}$ Program Studi Perikanan, Jurusan Peternakan Politeknik Negeri Lampung, Bandar Lampung \\ Jl. Soekarno-Hatta No. 10 Bandar Lampung \\ Penulis Korespodensi : warji1978@fp.unila.ac.id; warji1978@gmail.com
}

\begin{abstract}
Abstrak
Ikan rucah adalah ikan-ikan kecil yang ikut tertangkap nelayan selain ikan konsumsi. Ikan rucah memiliki potensi sebagai sumber protein hewani pakan ternak dan ikan. Ikan rucah selama ini belum termanfaatkan secara optimal, oleh karena itu Tim Pengabdian melakukan kegiatan penerapan mesin pembuat tepung ikan rucah. Tepung ikan rucah diharapkan dapat dimanfaatkan sebagai bahan pembuatan pakan teknak dan ikan tawar; sehingga ikan rucah dimanfaatkan secara optimal dan nilai ekonominya dapat meningkat. Metode pengabdian ini adalah dengan menerapkan mesin pembuat tepung ikan hasil rancang bangun Jurusan Ilmu Keteknikan Pertanian, Fakultas Pertanian, Universitas Lampung. Pengabdian ini juga menyampaikan wawasan dan pengetahuan tentang aspek-aspek dasar pengoperasian mesin penepung, perawatan dan pemanfaatan tepung ikan. Kegiatan penerapan mesin penepung berlajan dengan baik, proses pembuatan tepung ikan rucah dapat dilakukan dengan lebih mudah dan kapasitasnya mencapai 100-300 kg/hari. Mitra pengabdian mampu menyerap pengetahuan dan penjelasan yang disampaikan oleh Tim pengabdian sehingga mereka mampu mengoperasikan mesin penepung, melakukan perawatan dan mampu menangani tepung yang dihasilkan. Keberlanjutan program ini diharapkan mampu menghasilkan produk-produk turunan dari tepung ikan rucah sehingga dapat meningkatkan perekonomian masyarakat nelayan.
\end{abstract}

Kata kunci: ikan rucah, mesin penepung, tepung ikan

\section{Pendahuluan}

Lampung Timur merupakan kabupaten di bagian timur Propinsi Lampung dengan luas wilayah 5.325,03 $\mathrm{km}^{2}$. Bagian timur wilayah kabupaten ini berbatasan dengan Laut Jawa sehingga sebagian besar masyarakat di sepanjang pantai timur Lampung ini berprofesi sebagai nelayan tangkap maupun budidaya. Salah satu daerah yang menjadi sentra penghasil ikan di kabupaten ini adalah Kecamatan Pasir Sakti.

Kecamatan Pasir Sakti secara administratif memiliki delapan desa definitif, yakni desa: Pasir Sakti, Mekarsari, Rejo Mulyo, Kedung Ringin, Purworejo, Labuhan Ratu, Sumur Kucing, dan Mulyo Sari. Jumlah penduduk saat ini lebih kurang 30.000 orang, sebagian besar di antaranya bekerja sebagai nelayan, petambak dan petani.

Banyak jenis ikan yang dihasilkan, diolah dan dipasarkan oleh masyarakat setempat, seperti ikan teri nasi, golok-golok, cumi, kuro, pari, sembilang, tongkol, rajungan, dan kembung untuk jenis ikan tangkap; udang windu, bandeng, dan kepiting untuk ikan hasil budidaya. Selain jenis ikan yang sudah disebutkan tadi ada jenis ikan berukuran kecil yang disebut dengan ikan rucah. Ikan rucah merupakan ikan-ikan kecil dengan ukuran sekitar $10 \mathrm{~cm}$ yang ikut tertangkap oleh nelayan, jenis yang masuk dalam kelompok ini antara lain ikan pari, cucut, tembang, kuniran, rebon, selar, krisi dan sejenisnya. Biasanya nelayan menjual ikan tersebut dengan harga murah. Selain itu, pemanfaatan ikan rucah kurang maksimal, biasanya hanya untuk pakan ternak, ikan asin, atau pun hanya dibuang begitu saja. Sementara Koesoemawardani (2009) menyampaikan bahwa dengan sedikit teknologi ikan rucah dapat dimanfaatkan sebagai bahan baku pengolahan ikan. Peningkatkan nilai tambah ikan rucah memerlukan terobosan teknologi dan usaha agribisnis yang terencana secara komprehensif. Ikan rucah memiliki potensi sebagai bahan komplementer pakan ternak dan ikan tawar. 
Ketersediaan bahan baku yang melimpah dengan harga yang murah memungkinkan ikan rucah digunakan sebagai bahan baku pembuatan pakan.

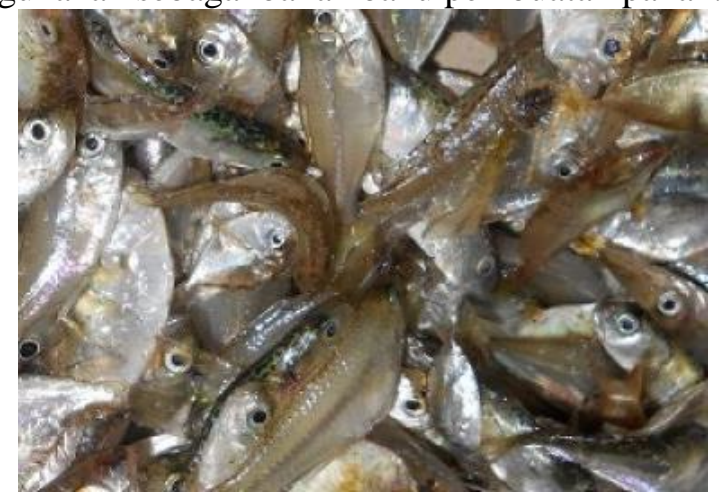

Gambar 1. Ikan rucah basah

Salah satu pengolahan ikan rucah adalah dijadikan tepung ikan rucah. Ikan rucah dalam bentuk tepung sangat mudah digunakan sebagai bahan baku industri, khususnya untuk pakan ternak atau sebagai pakan ikan. Pembuatan tepung ikan tersebut memerlukan adanya mesin penepung, salah satu mesin penepung yang bisa diterapkan adalah mesin penepung disk mill yang dimodifikasi dan dirancang bangun di Jurusan Ilmu Keteknikan Pertanian, Fakultas Pertanian, Universitas Lampung (Warji, 2010; Warji, 2011).

Rancangan mesin penepung ikan rucah tipe disk mill meliputi beberapa bagian: kerangka, hopper, ruang penepungan, saluran pengeluaran, saringan, puli, dan motor penggerak. Prinsip kerja mesin penepung ikan rucah adalah prinsip pemukulan bahan yang ditempatkan dalam ruang penepungan dengan menggunakan bilah pin yang dipasangkan pada lempengan atau disk.

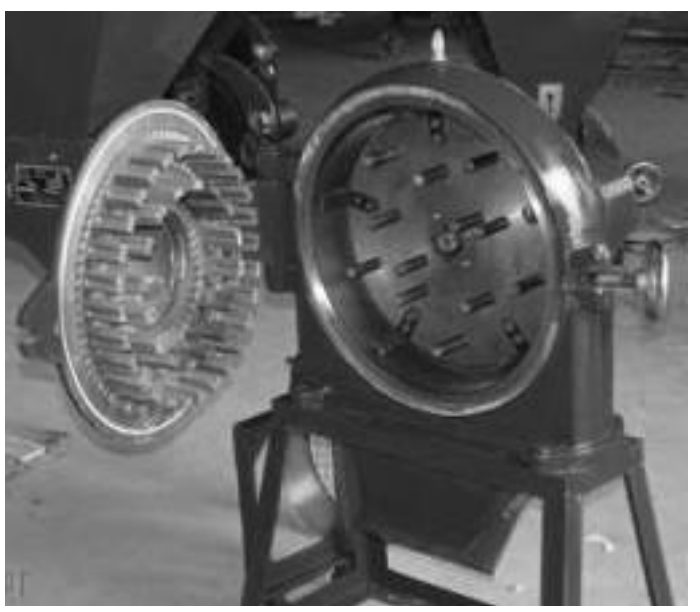

Gambar 2. Pin disk mill
Mekanisme kerja disk mill untuk menggiling/menghancurkan ikan rucah adalah dalam ruang penepung terdiri dari tiga langkah kerja, yaitu: material masuk dalam ruang penggiling melalui feeder/hopper, dan karena pengaruh gravitasi material yang masuk bertumbukan dengan sekumpulan pin yang melekat pada disk dalam ruang penepung. Pin berputar dengan kecepatan tinggi sehingga material dapat dihancurkan oleh tumbukan pin dan gesekan pada bidang disk yang berulang-ulang dan gesekan dengan dinding ruang penepung. Material yang sudah dihancurkan/ dihaluskan turun ke bawah karena gravitasi dan terdorong oleh adanya gaya putar pada poros melewati saringan atau ayakan yang selanjutnya menuju saluran pengeluaran. Tepung yang dihasilkan ditampung dengan menggunakan wadah yang terbuat dari kain penyaring.

\section{Bahan dan Metode}

A. Kerangka dan realisasi pemecahan masalah

Permasalahan rendahnya nilai jual ikan rucah dan potensinya yang cukup besar diselesaikan dengan mengubah ikan rucah menjadi tepung ikan rucah. Tepung ikan yang dihasilkan dapat dimanfaatkan menjadi bahan pakan ternak dan sejenisnya, sehingga diharapkan mampu meningkatkan nilai ekonomi ikan rucah.

\section{B. Khalayak sasaran}

Khalayak sasaran kegiatan pengabdian ini adalah Kelompok Pengolahan Ikan (PokLahKan) Mina Sakti Mandiri di Kecamatan Pasir Sakti, Kabupaten Lampung Timur, Propinsi Lampung, dimana rata-rata mereka adalah nelayan tangkap dan pengolah ikan hasil tangkapan.

\section{Metode pengabdian}

Metode yang ditawarkan dalam menyelesaikan permasalahan mitra dalam program pengabdian kepada masyarakat ini adalah dengan mengaplikasikan mesin penepung (disk mill) pada Kelompok Pengolahan Ikan (PokLahKan) Mina Sakti Mandiri di Kecamatan Pasir Sakti, Kabupaten Lampung Timur, Propinsi Lampung.

\section{Hasil dan Pembahasan}

Kegiatan pengabdian ini berhasil menerapkan mesin penepung pada Kelompok Pengolahan Ikan (PokLahKan) Mina Sakti Mandiri di Kecamatan Pasir Sakti, Kabupaten Lampung 
Timur. Tim pengabdian melakukan perancangan dan perakitan mesin penepung sesuai dengan yang dibutuhkan kelompok pengolahan ikan. Penepung ini digunakan untuk mengolah/menepungkan ikan rucah kering menjadi tepung ikan rucah. Ikan rucah kering ini memiliki kandungan protein yang tinggi sehingga cocok digunakan sebagai sumber protein hewani pakan ternak atau budidaya ikan tambak. Mesin penepung yang diterapkan disajikan pada Gambar 2. Sementara ikan rucah dan tepung ikan rucah disajikan pada Gambar 3 dan 4.

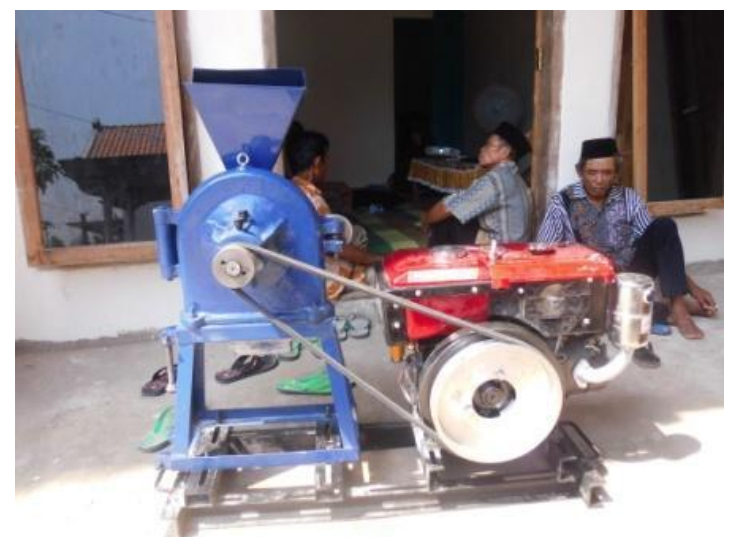

Gambar 3. Mesin penepung

Berdasarkan hasil uji coba pembuatan tepung bahwa ikan rucah dapat ditepungkan dengan menggunakan mesin penepung. Perlu diketahui bahwa ikan rucah yang sudah diasinkan hasil tepungnya cenderung menggumpal karena agak lengket, sementara ikan rucah tawar kering dapat ditepungkan dengan baik. Sehingga disarankan untuk membuat tepung ikan rucah sebaiknya menggunakan ikan rucah tawar.

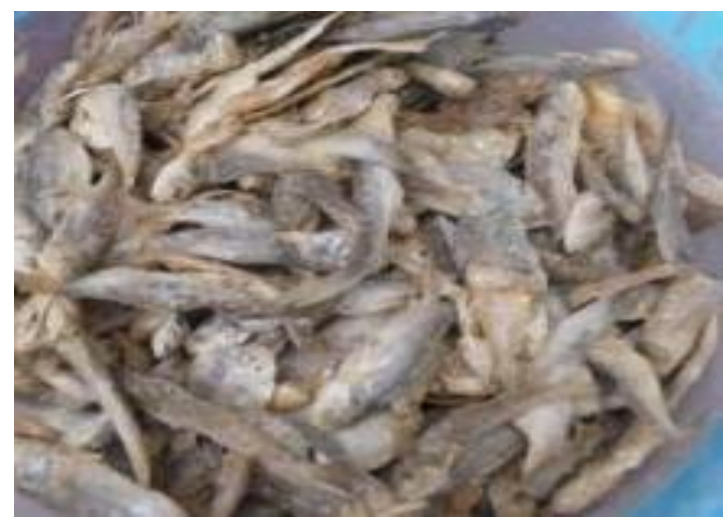

Gambar 4. Ikan rucah kering

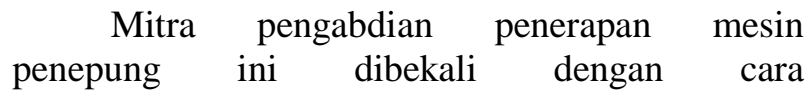

mengoperasikan, melakukan perawatan mesin penepungan dan menangani tepung yang dihasilkan. Peserta terlihat antusias dan mampu menyerap materi yang disampaikan oleh Tim pengabdian, hal ini ditunjukkan oleh kemampuan mereka mengoperasikan mesin penepung. Kegiatan pengoperasian dan perawatan mesin penepung disajikan pada Gambar 5 dan 6.

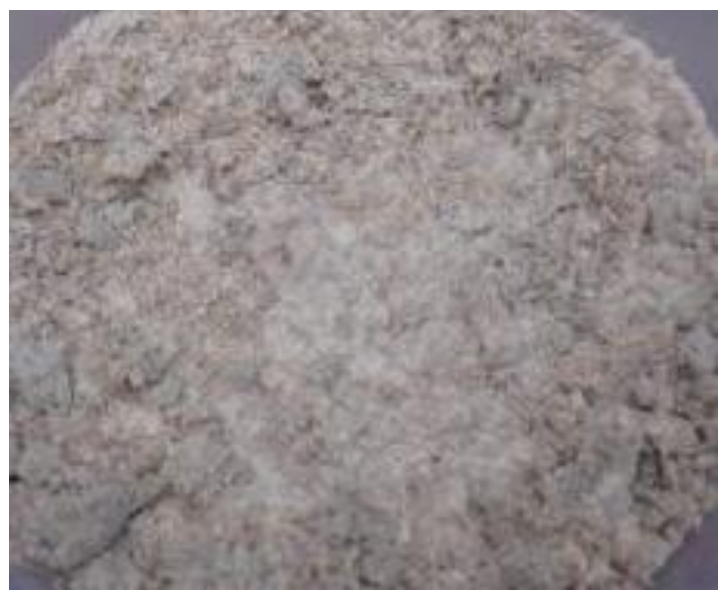

Gambar 5. Tepung ikan rucah

Selain melakukan aplikasi mesin penepung, kegiatan pengabdian ini juga memberikan pengetahuan tentang agribisnis ikan rucah sebagai sumber protein hewani bagi pakan ternak (ikan atau unggas) pada masyarakat nelayan. Kegiatan penjelasan penggunaan atau pemanfaatan tepung disajikan pada Gambar 7.

Tim pengabdian juga melakukan pendampingan terhadap mitra sehingga mereka dapat melakukan pembuatan tepung dengan baik. Tepung yang mereka hasilkan mereka gunakan untuk pakan ikan tawar yang mereka budidayakan dan untuk pakan ternak.

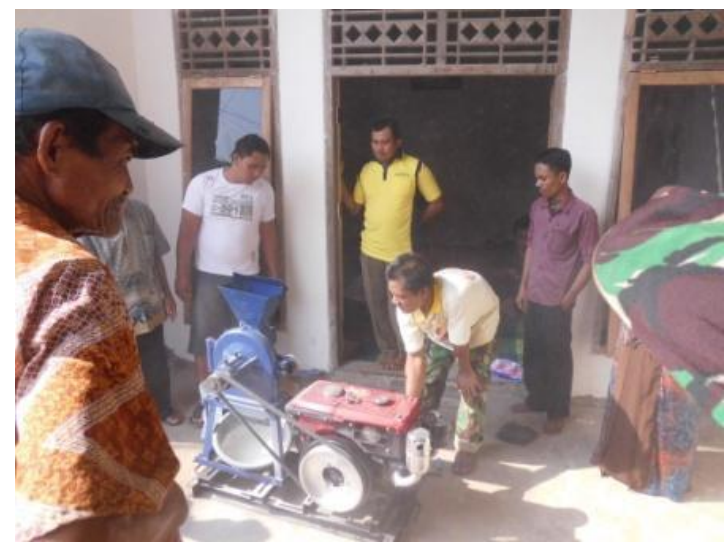

Gambar 6. Perawatan mesin penepung 
Mitra pengabdian juga mulai melakukan produksi tepung untuk di jual. Perlu dikatahui bahwa awalnya kelompok pengolah ikan ini memanfaatkan ikan rucah secara langsung tanpa ditepungkan. Sementara setelah aplikasi mesin penepung ini kapasitas produksi tepung mencapai $100 \mathrm{~kg}$ sampai $300 \mathrm{~kg}$ per hari, tergantung ketersediaan bahan baku. Sementara penyediaan bahan baku terkendala oleh pengeringan, selama ini pengeringannya hanya mengandalkan pada sinar matahari, penjemuran menggunakan sinar matahari. Oleh karenanya ketua kelompok pengolah ikan mengusulkan adanya aplikasi alat pengering hybrid, memanfaatkan sinar matahari dan energi lain. Alat pengering yang merekaperlukan sudah dirancang bangun di Jurusan Ilmu Keteknikan Pertanian FP UNILA (Asmara dan Warji, 2011; Sari et al., 2014) dan siap untuk diaplikasikan.

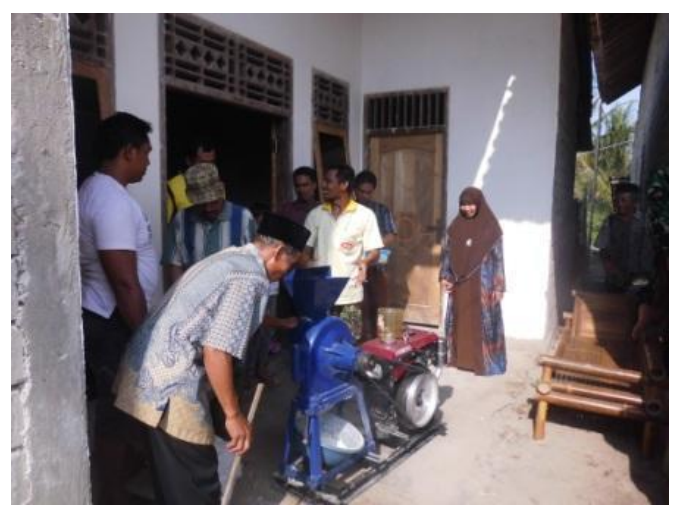

Gambar 7. Penepungan ikan rucah

Sementara pemantauan Tim pengabdian terhadap keberlanjutan program menunjukkan hasil yang menggembirakan bahwa kelompok pengolahan ikan serius memafaatkan tepung ikan rucah untuk membuat pakan ikan dan ternak. Mitra juga mulai kerjasama dengan para nelayan untuk menyediakan bahan baku ikan rucah. Kelompok pengolahan ikan juga mengupayakan pembuatan mesin pembuat pelet (pakan ikan) dan peralatan lain untuk memanfaatkan tepung ikan menjadi produk yang lebih tinggi harganya. Keberlanjutan program ini diharapkan mampu menghasilkan produk-produk turunan dari tepung ikan rucah sehingga dapat meningkatkan perekonomian masyarakat nelayan.

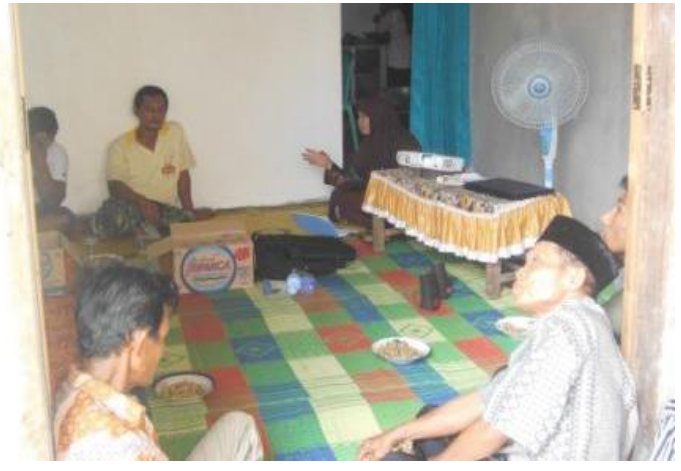

Gambar 8. Penjelasan manfaat tepung ikan

\section{Kesimpulan}

Kegiatan penerapan mesin penepung dapat berjalan dengan baik. Proses pembuatan tepung ikan rucah dapat dilakukan dengan lebih mudah dan kapasitasnya mencapai $100-300 \mathrm{~kg}$ per hari. Tepung ikan rucah sebaiknya dibuat dari ikan rucah tawar. Perlu adanya pengabdian serupa untuk mengaplikasikan mesin pengering hybrid sehingga dapat membantu pengeringan ikan rucah.

\section{Ucapan Terima Kasih}

Ucapan terima kasih disampaikan kepada KEMENRISTEK DIKTI yang telah membiayai kegiatan pengabdian ini melalui hibah Ipteks bagi Masyarakat (IbM) Tahun Anggaran 2013. Terima kasih juga disampaikan kepada Kelompok Pengolahan Ikan (PokLahKan) Mina Sakti Mandiri di Kecamatan Pasir Sakti, Kabupaten Lampung Timur, Propinsi Lampung khususnya kepada Bapak Anshori sebagai ketua Kelompok atas kerjasamanya sehingga pengabdian ini dapat terlaksana dengan baik.

\section{Daftar Pustaka}

Asmara, S., \& Warji. 2010. Kinerja Pengeringan Chip Ubikayu. Jurnal Keteknikan Pertanian, 24(2): 75-80.

Koesoemawardani, D. 2009. Kajian Hidrolisat Protein dari Ikan Rucah Sebagai Bahan Fortifikasi Makanan. Seminar Hasil-Hasil Penelitian dan Pengabdian Universitas Lampung 2009. Lampung.

Sari, I. N., Warji, \& Novita, D. D. 2014. Uji Kinerja Alat pengering Hybrid Tipe Rak pada Pengeringan Chip Pisang Kepok. Jurnal Teknik Pertanian Lampung, 3(1): 59-68.

Warji. 2010. Rancang Bangun Mesin Penepung Ubi Kayu Tipe Hammer Mill. Jurnal Enjinering Pertanian, 7(120): 91-98. 
SAKAI SAMBAYAN — Jurnal Pengabdian kepada Masyarakat

Warji. 2011. Uji Kinerja Mesin Penepung Ubi

Dekan

(Semirata).

Palembang.

Kayu. Tipe Hammer Mill. Seminar Nasional dan Rapat 